\title{
APLIKASI KEAMANAN LEMBAR HASIL STUDI MENGGUNAKAN ALGORITMA MESSAGE DIGEST 5 Studi Kasus : Fakultas Teknik Universitas Muhammadiyah Bengkulu
}

\author{
Yovi Apridiansyah $^{1}$, Muhammad Husni Rifqo ${ }^{2}$ \\ ${ }^{1,2}$ Program Studi Informatika, Fakultas Teknik, Universitas Muhammadiyah Bengkulu \\ Jl. Bali, Bengkulu 38119 \\ ${ }^{1}$ yoviapridiansyah@gmail.com \\ ${ }^{2}$ kokoahzani@gmail.com
}

\begin{abstract}
Abstrak: Keamanan komputer merupakan tindakan pencegahan dari serangan pengguna komputer atau pengakses jaringan yang tidak bertanggung jawab (D.Howard, 1997). Dengan adanya keamanan komputer dapat mencegah tindak kejahatan dalam bidang komputer. Salah satu metode keamanan komputer yaitu dengan menggunakan Algoritma Message Digest 5 untuk keaman LHS dengan menerapkan MD5 file dapat di enkripsi dan didekripsi oleh user. Dengan menggunakan metode algoritma missage digest 5 yang mempunyai fungsi hash (prosedur terdefinisi atau fungsi matematika yang mengubah variabel dari suatu data yang berukuran besar menjadi lebih sederhana) kriptografi yang digunakan secara luas dengan hash value 128-bit. MD5 dimanfaatkan dalam berbagai aplikasi keamanan, dan umumnya digunakan untuk menguji integritas sebuah file. Tujuan dari penelitian ini diharapkan informasi dari LHS tersebut dapat terjaga dengan baik tanpa dapat dimanipulasi oleh orang lain untuk merusak informasi yang ada. Dengan adanya aplikasi keamanan LHS menggunakan algoritma MD5 diharapakan dapat mempermudah mahasiswa, pertama dengan adanya sistem keamanan LHS pada Fakultas Teknik Universitas Muhammadiyah Bengkulu ini informasi keaslian LHS tidak dapat dimanipulasi oleh pihak lain. Kedua, dengan adanya aplikasi keamanan ini dapat mempermudah mahasiswa dalam melihat lembar hasil studi mereka.
\end{abstract}

Kata Kunci : Kriptografi, Enkripsi, Dekripsi, MD5

Abstarct: Computer security is measures the prevention of attacks for the user or a network userunresponsible (D.Howard, 1997). With the security of your computer can prevent crimes in the field of the computer. One of the computer security motede namely using the Missage Digest 5 algorithm for security LHS by applying MD5 files can be in the encryption and decrypted by the user. By using this method the missage digest 5 algorithm that have a hash function (Undefined selection procedure or function of mathematics which change the variables from a large amounts of data to be more simple) cryptographic used widely with hash value 128-bit. MD5 utilized in various security applications and generally used to testing file integrity. The purpose of this research is expected information from the LHS can be well maintained without can be manipulated by other people to damage the existing information. With the existence of the security applications using LHS MD5 hope algorithm can facilitate the students, first with the existence of the security system on the LHS Faculty of Engineering Muhammadiyah University of Bengkulu is genuine LHS information cannot be manipulated by the other party. The second, with the existence of this security application can facilitate the students in view of their study results sheet. Keywords: cryptography, encryption, decrypt, MD5 


\section{PENDAHULUAN}

Teknologi memiliki peran penting dalam perkembangan umat manusia, terutama ketika manusia mengelola organisasi. Konsep teknologi berimplikasi bahwa setiap kegiatan administrasi dan manajemen merupakan teknologi dan pasti memerlukan teknologi. Posisi teknologi tersebut semakin lebih penting ketika inovasi tersebut berhasil menggabungkan teknologi informasi dan telekomunikasi (misalnya internet). Penggunaan teknologi informasi dan komunikasi ternyata membuat kinerja organisasi lebih efektif, efisien dan kompetitif [1].

Dalam perkembangannya, bukan hanya informasi yang menjadi penting, tetapi perkembangan teknologi pun menjadi hal yang sangat penting khususnya teknologi keamanan komputer. Sebagai contoh, sekarang ini manusia berlomba-lomba membangun sebuah sistem untuk melindungi informasi yang mereka miliki dari ancaman virus ataupun orang lain yang berusaha untuk mengambil, memanipulasi ataupun hanya untuk sekedar merusak informasi itu.

Berbagai aplikasi sistem informasi dibidang pendidikan, antara lain: Sistem Informasi Akademik (SIA), e-learning, e-library, eassesment, etutor, portal pendidikan dan berbagai aplikasi lainnya memberikan kemudahan kepada stake holder (mahasiswa, dosen, staff administrasi, eksekutif dan bagian luar kampus) disebuah perguruan tinggi untuk melaksanakan Tridharma perguruan tinggi dan meningkatkan kualitas pembelajaran dan pelayanan. SIA yang telah banyak diimplementasikan diberbagai kampus di Indonesia telah memberikan dampak kemudahan dari berbagai kampus untuk mengelola administrasi kegiatan akademik mahasiswa dan kampus, seperti informasi data mahasiswa, nilai, informasi jadwal, materi kuliah dari setiap dosen pengajar dan beberapa informasi lainnya [2]

Sistem informasi akademik di Universitas Muhammadiyah Bengkulu khususnya berupa layanan online (website) berperan aktif pada kegiatan penunjang kegiatan perkuliahan, dalam penelitian ini penulis mengimplementasikan keamanan LHS online yang ada pada Fakultas Teknik Universitas Muhammadiyah Bengkulu. Berdasarkan studi kasus pada sistem akademik yang ada pada Universitas Muhammadiyah Bengkulu, penelitian menerapkan bagaimana algoritma MD5 untuk keamanan LHS. Penelitian ini penting dilakukan untuk keamanan LHS mahasiswa dari bentuk virus ataupun orang lain yang berusaha untuk mengambil, memanipulasi ataupun hanya untuk sekedar merusak informasi itu.

Dengan menggunakan metode algoritma message digest 5. Algoritma ini mempunyai fungsi hash (prosedur terdefinisi atau fungsi matematika yang mengubah variabel dari suatu data yang berukuran besar menjadi lebih sederhana) kriptografi yang digunakan secara luas dengan hash value 128-bit. MD5 dimanfaatkan dalam berbagai aplikasi keamanan, dan umumnya digunakan untuk meguji integritas sebuah file. Dengan adanya sebuah sistem keamanan untuk LHS online ini diharapkan informasi dari LHS tersebut dapat terjaga dengan baik tanpa dapat dimanipulasi oleh orang lain untuk merusak informasi yang ada. 


\section{LANDASAN TEORI}

\section{A. Enkripsi}

Proses utama dalam suatu algoritma kriptografi adalah enkripsi dan dekripsi. Enkripsi merubah sebuah plaintext ke dalam bentuk ciphertext. Pada mode ECB (Elekctronic Codebook), sebuah blok pada plaintext dienkripsi ke dalam sebuah blok ciphertext dengan panjang blok yang sama. Blok cipher memiliki sifat bahwa setiap blok harus memiliki panjang yang sama (misalnya 128 bit). Namun apabila pesan yang dienkripsi memiliki panjang blok terakhir tidak tepat 128 bit, maka diperlukan mekanisme padding, yaitu penambahan bit-bit dummies untuk menggenapi menjadi panjang blok yang sesuai; biasanya padding dilakukan pada blok terakhir plaintext. Padding bada blok terakhir bisa dilakukan dengan berbagai macam cara, misalnya dengan penambahan bit-bit tertentu. Salah satu contoh penerapan padding dengan cara menambahkan jumlah total padding sebagai byte terakhir pada blok terakhir plaintext. Misalnya panjang blok adalah 128 bit (16 byte) dan pada blok terakhir terdiri dari 88 bit (11 byte) sehingga jumlah padding yang diperlukan adalah 5 byte, yaitu dengan menambahkan angka nol sebanyak 4 byte, kemudian menambahkan angka 5 sebanyak satu byte. Cara lain dapat juga menggunakan penambahan karakter end-of-file pada byte terakhir lalu diberi padding setelahnya [2].

\section{B. Dekripsi}

Dekripsi merupakan proses kebalikan dari proses enkripsi, merubah ciphertext kembali ke dalam bentuk plaintext. Untuk menghilangkan padding yang diberikan pada saat proses enkripsi, dilakukan berdasarkan informasi jumlah padding yaitu angka pada byte terakhir setelahnya [3].

\section{LEMBAR HASIL STUDI (LHS)}

Lembar Hasil Studi atau LHS adalah kartu yang menunjukkan nilai dan prestasi mahasiswa pada semester tertentu. Lembar Hasil Studi dapat didownload dan dicetak oleh mahasiswa bersangkutan pada system akademik tempat kuliah masing-masing. LHS yang dicetak oleh mahasiswa tidak dapat digunakan dalam proses administrasi akademik. Oleh karena itu, setiap semester, mahasiswa harus meminta LHS yang dicetak dan disahkan oleh program studi bersangkutan. Selain menyimpan nilai di database, program studi juga harus menyimpan LHS yang dicetak dan disahkan.

\section{A. Algoritma Message Digest 5}

MD5 merupakan singkatan dari MessageDigest algortihm 5, adalah fungsi hash (prosedur terdefinisi atau fungsi matematika yang mengubah variabel dari suatu data yang berukuran besar menjadi lebih sederhana) kriptografik yang digunakan secara luas dengan hash value 128-bit. MD5 dimanfaatkan dalam berbagai aplikasi keamanan, dan umumnya digunakan untuk meguji integritas sebuah file. Enkripsi menggunakan MD5 masih mendominasi sebagian besar aplikasi PHP. Enkripsi MD5 dianggap strong karena enkripsi yang dihasilkannya bersifat 'one way hash'. Berapapun string yang di enkripsi hasilnya tetap sepanjang 32 karakter [4].

Message Digest 5 (MD5) juga merupakan salah satu dari serangkaian algoritma Message Digest yang didesain oleh Professor Ronald Rivest dari MIT. Saat kerja analitik menunjukkan bahwa pendahulu MD5 -MD4- mulai tidak aman, MD5 kemudian didesain pada tahun 1991 sebagai pengganti dari MD4 (kelemahan MD4 ditemukan 
oleh Hans Dobbertin). MD5 banyak digunakan pada bermacam macam aplikasi termasuk SSL/TLS, IPSec dan protokol-protokol kriptografi lainnya. MD5 juga biasa digunakan pada implementasi Timestamping Mechanism, Commitment Schemes, dan aplikasi pengecekan integritas pada online software. MD5 tidak memiliki sistem pengamanan seperti persamaan matematika, namun untuk setiap fungsi hash , domain $\mathrm{D}$ dan range $\mathrm{R}$ kita membutuhkan tiga hal berikut :

1. Pre Image Resistance : jika diberi suatu nilai y $\varepsilon \mathrm{R}$, maka kita tidak akan dapat mencari suatu nilai $\mathrm{x} \varepsilon \mathrm{D}$ dimana $\mathrm{h}(\mathrm{x})=\mathrm{y}$.

2. Second Pre Image Resistance : jika diberi suatu nilai $\mathrm{x} \varepsilon \mathrm{D}$, maka kita tidak akan dapat mencari nilai $\mathrm{x}^{\prime} \varepsilon \mathrm{D}$ dimana $\mathrm{h}(\mathrm{x})=\mathrm{h}\left(\mathrm{x}^{\prime}\right)$.

3. Collision Resistance : kita tidak akan dapat mencari nilai $\mathrm{x}, \mathrm{x}^{\prime} \varepsilon \mathrm{D}$ dimana $\mathrm{h}(\mathrm{x})=\mathrm{h}\left(\mathrm{x}^{\prime}\right)$.

Fungsi hash yang banyak digunakan dalam kriptografi MD5 ini fungsi hash yang digunakan algoritma MD5. MD5 menerima masukan berupa pesan dengan ukuran sembarang dan menghasilkan message digest yang panjangnya 128 bit . Langkah-langkah dalam pembuatan message digest secara garis besar adalah sebagai berikut:

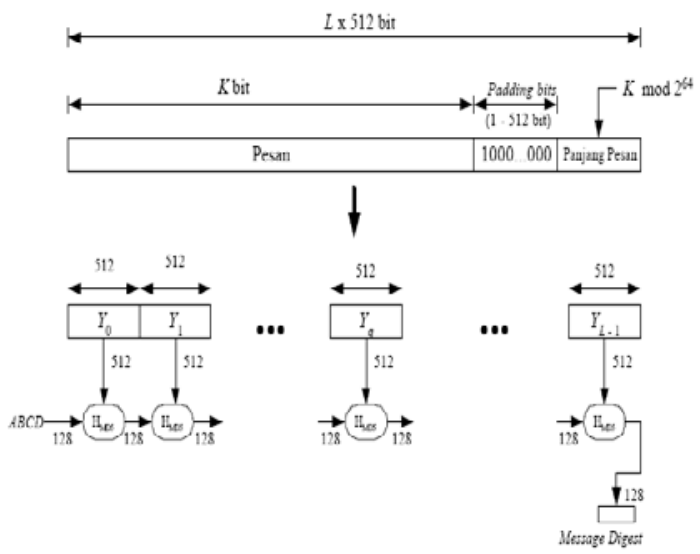

Gambar 1. Pembuatan message digest dengan algoritma MD5
Menilik dari gambar diatas, secara garis besar pembuatan message digest ditempuh melalui empat langkah, yaitu :

1. Penambahan bit-bit pengganjal (padding bits).

- Pesan ditambah dengan sejumlah bit pengganjal sedemikian hingga panjang pesan (dalam satuan bit) kongruen dengan 448 modulo 512

- Jika panjang pesan 448 bit, maka pesan tersebut ditambah dengan 512 bit menjadi 960 bit. Jadi, panjang bit-bit pengganjal adalah dari 1 sampai 512.

- $\quad$ Bit-bit pengganjal terdiri dari sebuah bit 1 diikuti beberapa sisanya bit 0 .

2. Penambahan nilai panjang pesan semula.

- Pesan yang telah diberi bit-bit pengganjal selanjutnya ditambah lagi dengan 64 bit yang menyatakan panjang pesan semula.

- Jika panjang pesan > 264 maka yang diambil adalah panjangnya dalam modulo 264. Dengan kata lain, jika panjang pesan semula adalah $k$ bit, maka 64 bit yang ditambahkan menyatakan $k$ modulo 264.

- $\quad$ Setelah ditambah dengan 64 bit, panjang pesan sekarang menjadi kelipatan 512 bit.

3. Inisialisasi penyangga (buffer) MD.

- MD5 membutuhkan 4 buah penyangga (buffer) yang masing-masing panjangnya 32 bit. Total panjang penyangga adalah 4 x 32 = 128 bit.

- Keempat penyangga ini menampung hasil antara dan hasil akhir. Keempat penyangga ini diberi nama $\mathrm{A}, \mathrm{B}, \mathrm{C}$, dan D. Setiap penyangga diinisialisasi dengan nilai-nilai (dalam notasi $H E X$ ) sebagai berikut :

$$
\mathrm{A}=01234567
$$




$$
\begin{aligned}
& \mathrm{B}=\text { 89ABCDEF } \\
& \mathrm{C}=\text { FEDCBA98 } \\
& \mathrm{D}=76543210
\end{aligned}
$$

Pengolahan pesan dalam blok berukuran 512 bit. Proses berikutnya adalah pesan dibagi menjadi L buah blok yang masing-masing panjangnya 512 bit $\left(\mathrm{Y}_{0}\right.$ sampai $\left.\mathrm{Y}_{\mathrm{L}-1}\right)$. Setelah itu setiap blok 512 bit diproses bersama dengan penyangga MD yang menghasilkan keluaran 128 bit, dan ini disebut $\mathrm{H}_{\mathrm{MD} 5}$.

\section{MEtode PENELITIAN}

Dalam penelitian ini model pengembangan sistem yang digunakan yaitu model incremental. Incremental model merupakan model pengembangan sistem pada software engineering berdasarkan requirement software yang dipecah menjadi beberapa fungsi atau bagian sehingga model pengembangannya secara bertahap. dilain pihak ada mengartikan model incremental sebagai perbaikan dari model waterfall dan sebagai standar pendekatan topdown.

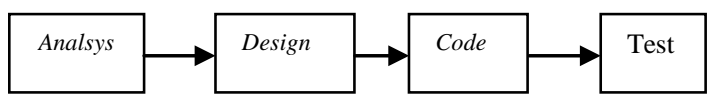

Gambar 2. Desain Pemodelan Incremental

\section{Analisis}

Analisis data diartikan sebagai upaya mengolah data menjadi informasi, sehingga karakteristik atau sifat-sifat data tersebut dapat dengan mudah dipahami dan bermanfaat untuk menjawab masalah-masalah yang berkaitan dengan kegiatan penelitian.

\section{D.Design}

Dalam tahapan architecture design ini merupakan perancangan software yang terbuka agar dapat diterapkan sistem pembangunan perbagian pada tahapan selanjutnya. Dalam studi kasus penelitian ini yaitu Aplikasi Keamanan Lembar Hasil Studi Menggunakan Algoritma
Message Digest 5 (Studi Kasus Fakultas Teknik

Universitas Muhammadiyah Bengkulu).

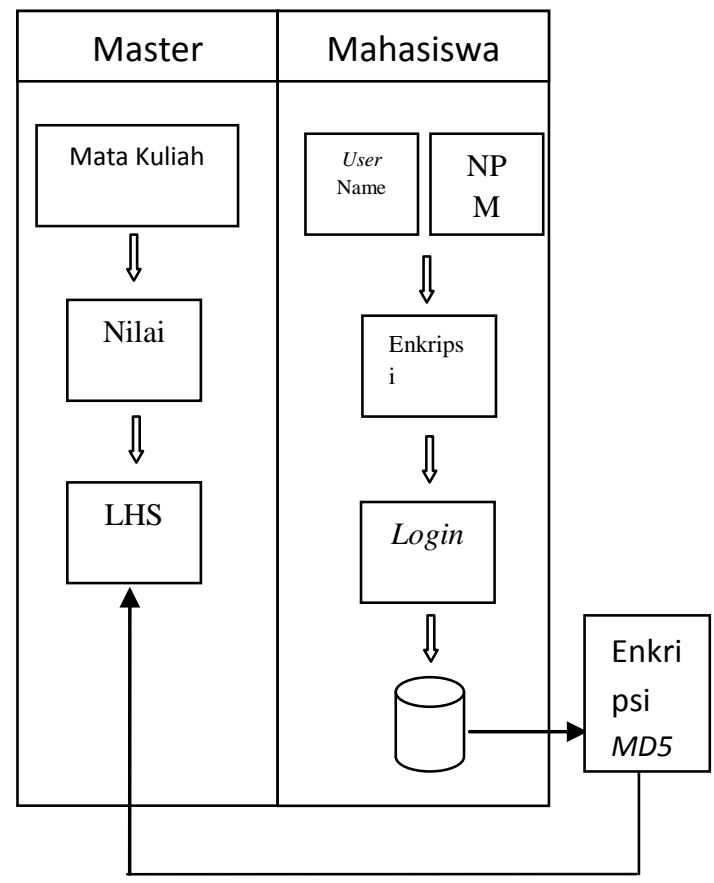

Gambar 3. Skema Enkripsi MD5

\section{E. Code}

Dalam tahapan code ini merupakan lanjutan dari proses design yang telah dikerjakan, untuk aplikasi keamanan lembar hasil studi menggunakan algoritma messege digest 5 studi kasus Fakultas Teknik Universitas Muhammadiyah Bengkulu yaitu menggunakan bahasa pemprograman PHP MySQL, Java dan Eclipse yang merupan aplikasi tambahan untuk algoritma message digest 5. Diharapkan nantinya dengan menggunakan program-program yang telah disebutkan diatas algoritma message disgest 5 dapat bekerja dengan baik dalam keamanan LHS.

Contoh Aplikasi Enkripsi MD5 misalnya, kata "supono" akan di enkripsi menggunakan message digest 5 akan berubah menjadi “9008a28a8a5d07db3091d9114a839268".

Jumlahnya akan menjadi 32 karakter, berapapun input, akan menghasilkan output enkripsi sejumlah 32. 
Jurnal Pseudocode, Volume II Nomor 2, September 2015, ISSN 2355 - 5920

\section{F. Test}

Dalam tahapan test ini merupakan proses lanjutan dari pengkodean program yang di buat. Dalam tahapan ini user melakukan pengujian dengan metode pengujian yang dipakai adalah black box testing. black box testing atau test fungsional adalah pengujian program yang dilakukan oleh pengembang (Programmer) dengan memberikan input tertentu dan melihat hasil yang didapatkan dari input tersebut. dengan kata lain, black box testing terfokus pada fungsionalitas sistem. dalam melaksanakan black box testing, penulis menggunakan beberapa kriteria yang akan diujikan. kriteria-kriteria tersebut antara lain :

1. Kemampuan Interface sistem untuk menjalankan fungsinya.

2. Kemampuan sistem untuk menjalankan fungsi interface.

3. Kemampuan sistem untuk menangani inputinput form yang berada di luar boundary sistem.

4. Kemampuan sistem untuk menangani masalah keamanan.

\section{HASIL DAN PEMBAHASAN}

Pada tahap implementasi sistem, rancangan dan desain sistem diimplementasikan dengan bahasa pemrograman menggunakan bahasa pemrograman PHP MySQL.

A. Menu Utama

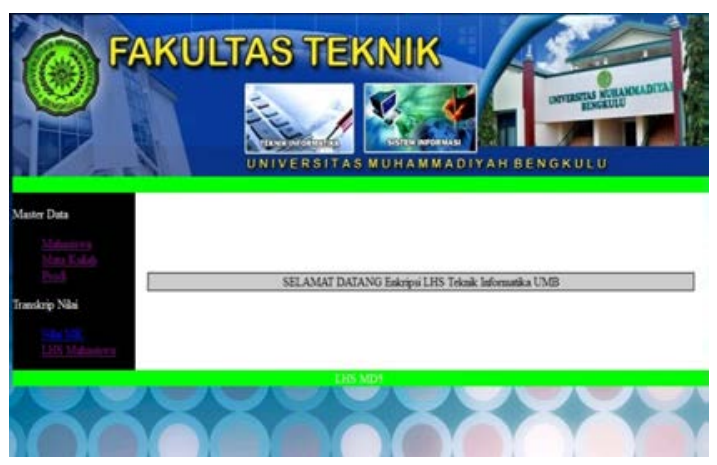

Tampilan menu utama ini terdapat master data yang terdiri dari sub menu Mahasiswa, Mata Kuliah Prodi dimana pada masing-masing sub menu tersebut untuk proses input data. Transkip Nilai yang terdiri dari Nilai mata kuliah dan LHS mahasiswa pada sub menu ini merupakan proses input data mata kuliah dan hasil LHS yang akan dicetak.

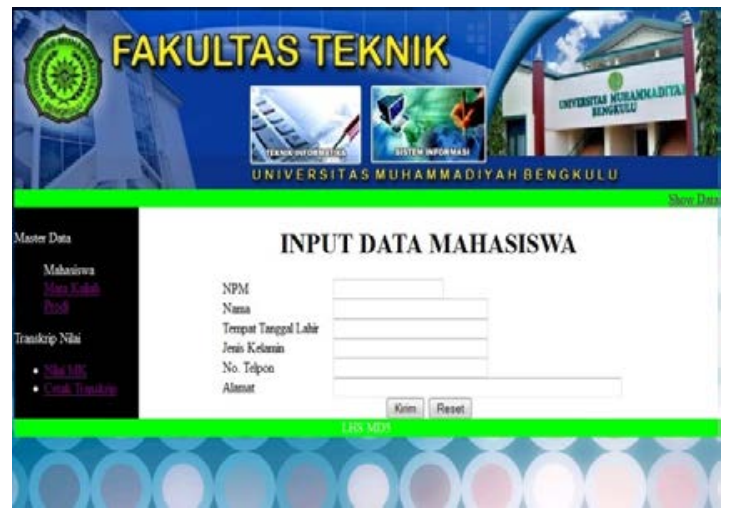

Gambar 5. Tampilan Input Data Mahasiswa

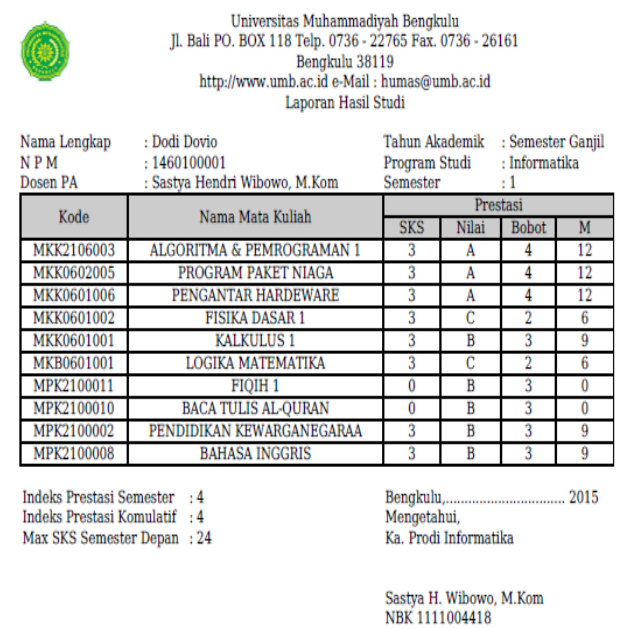

Gambar 6. LHS Mahasiswa

Proses selanjutnya simpan file pdf LHS mahasiswa ke local disk c- xampp-htdocslhsencrypt- passwordpdf-hasil. Setelah file pdf tersimpan maka proses selanjutnya yaitu enkripsi file agar kerahasian dalam informasi LHS dapat terjaga dengan aman.

Gambar 4. Tampilan Menu Utama Aplikasi 


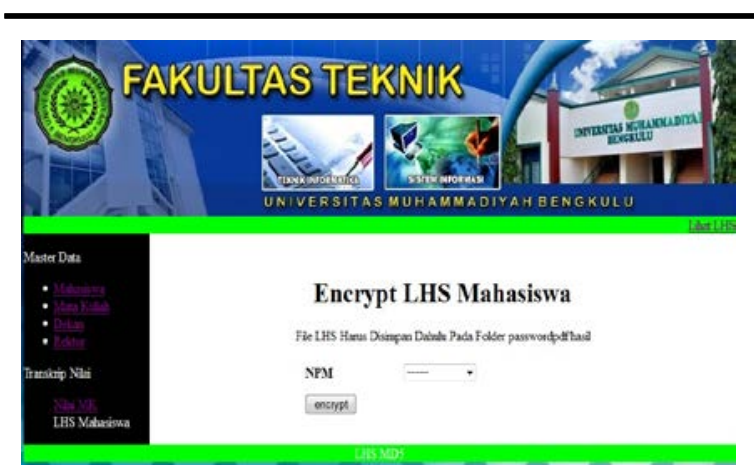

Gambar 7. Proses Enkripsi LHS

Adapun proses enkripsi menggunakan algoritma MD5 sebagai berikut :

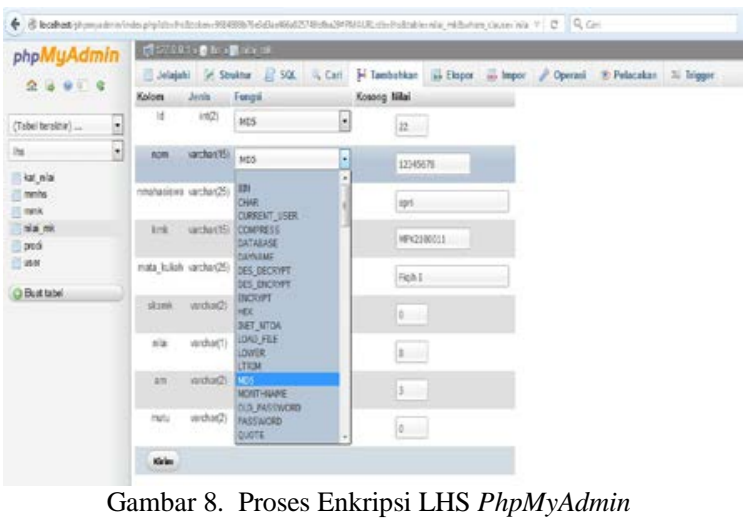

Dari gambar diatas dapat dijelaskan bahwa proses enkripsi menggunakan algoritma MD5 dapat digunakan langsung menggunakan PhpMyAdmin yang merupakan perangkat lunak gratis yang ditulis dalam $P H P$, dimaksudkan untuk menangani administrasi MySQL melalui Web. PhpMyAdmin mendukung berbagai operasi pada MySQL (mengelola database, tabel, kolom, hubungan, indeks, pengguna, perizinan , dll) dapat dilakukan melalui antarmuka pengguna yang sering digunakan, karena didalam phpmyadmin telah terdapat langsung untuk proses enkripsi algoritma MD5 sehingga lebih memudahkan pengguna untuk melakukan proses pengenkripsian. Dengan menambahkan sedikit koding berikut :

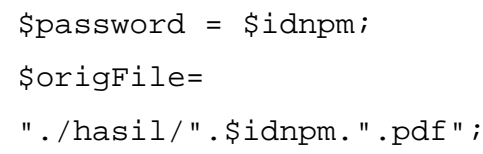$$
\text { ". /hasil/". \$idnpm.".pdf"; }
$$

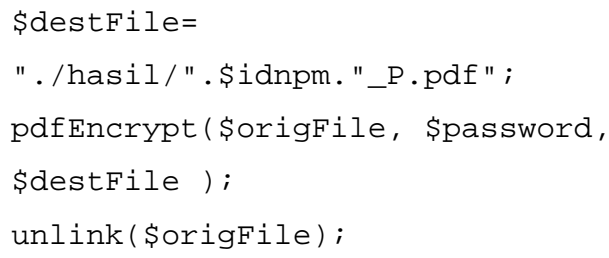

Setelah proses enkripsi selesai maka file pdf telah terekripsi dan terjaga keamanan LHSnya.

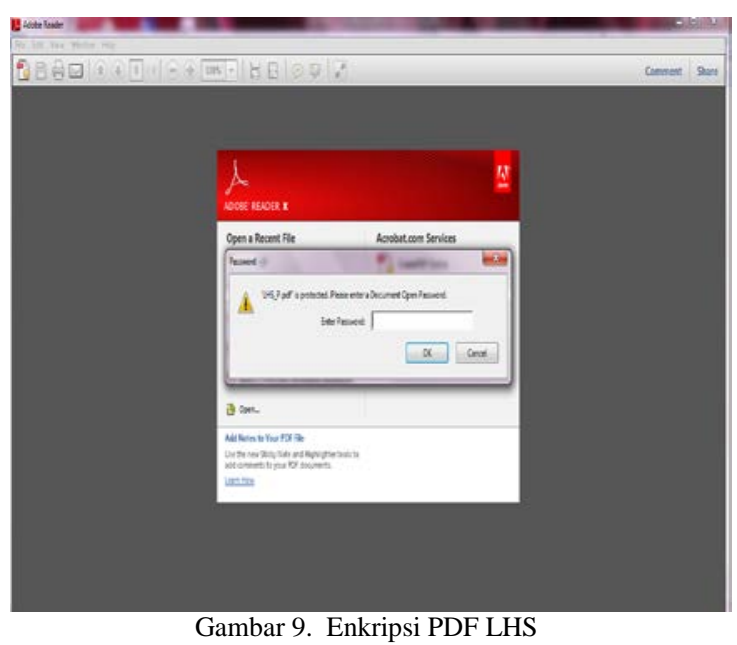

\section{Pengujian Sistem}

Pada penelitian ini pengujian sistem menggunakan Blackbox testing merupakan salah satu metode pengujian perangkat lunak yang berfokus pada sisi fungsionalitas, khususnya pada input dan output aplikasi (apakah sudah sesuai dengan apa yang diharapkan atau belum). Tahap pengujian atau testing merupakan salah satu tahap yang harus ada dalam sebuah siklus pengembangan perangkat lunak (selain tahap perancangan atau desain).

Tabel 1 Pengujian Black box

\begin{tabular}{|c|l|l|l|l|}
\hline No & $\begin{array}{l}\text { Skenario } \\
\text { Pengujian }\end{array}$ & $\begin{array}{c}\text { Hasil Yang } \\
\text { diharapkan }\end{array}$ & $\begin{array}{c}\text { Hasil } \\
\text { Pengujian }\end{array}$ & $\begin{array}{c}\text { Kesim } \\
\text { pulan }\end{array}$ \\
\hline 1 & $\begin{array}{l}\text { Tombol } \\
\text { Mahasiswa }\end{array}$ & $\begin{array}{l}\text { Masuk ke form } \\
\text { pengisian data } \\
\text { mahasiswa }\end{array}$ & $\begin{array}{l}\text { Sesuai } \\
\text { harapan }\end{array}$ & Valid \\
\hline 2 & $\begin{array}{l}\text { Tombol } \\
\text { Mata } \\
\text { Kuliah }\end{array}$ & $\begin{array}{l}\text { Masuk Ke } \\
\text { form mata } \\
\text { kuliah }\end{array}$ & $\begin{array}{l}\text { Sesuai } \\
\text { harapan }\end{array}$ & Valid \\
\hline 3 & $\begin{array}{l}\text { Tombol } \\
\text { Prodi }\end{array}$ & $\begin{array}{l}\text { Masuk ke } \\
\text { halam prodi } \\
\text { untuk } \\
\text { pengisian data } \\
\text { prodi }\end{array}$ & $\begin{array}{l}\text { Sesuai } \\
\text { harapan }\end{array}$ & Valid \\
\hline
\end{tabular}


Jurnal Pseudocode, Volume II Nomor 2, September 2015, ISSN 2355 - 5920

\begin{tabular}{|l|l|l|l|l|}
\hline 4 & $\begin{array}{l}\text { Tombol } \\
\text { Nilai Mata } \\
\text { Kuliah }\end{array}$ & $\begin{array}{l}\text { Masuk ke } \\
\text { pengisian data } \\
\text { nilai } \\
\text { mahasiswa }\end{array}$ & $\begin{array}{l}\text { Sesuai } \\
\text { harapan }\end{array}$ & Valid \\
\hline 5 & $\begin{array}{l}\text { Tombol } \\
\text { LHS } \\
\text { Mahasiswa }\end{array}$ & $\begin{array}{l}\text { Masuk ke } \\
\text { halaman untuk } \\
\text { melihat hasil } \\
\text { LHS } \\
\text { mahasiswa }\end{array}$ & $\begin{array}{l}\text { Sesuai } \\
\text { harapan }\end{array}$ & Valid \\
\hline
\end{tabular}

\section{Penutup}

Dari hasil penelitian ini dapat ditarik aplikasi yang di buat oleh Penulis dpat diperbaiki untuk proses yang lebih baik karena aplikasi yang penulis buat masih jauh dari sempurna, oleh karena itu masih banyak yang harus dikembangkan dalam rancangan ini. Misalnya penggunaan action script yang masih sederhana serta sedikitnya pengetahuan yang dimiliki oleh penulis tentang program PHP MySQL.

kesimpulan sebagai berikut :

1. Dengan adanya sistem keamanan LHS pada

Fakultas Teknik Universitas Muhammadiyah Bengkulu ini informasi keaslian LHS tidak dapat dimanipulasi oleh pihak lain.

2. Dengan adanya aplikasi keamanan ini dapat mempermudah mahasiswa dalam melihat, lembar hasil studi mereka.

Dari kesimpulan di atas maka penulis mengajukan saran yang diharapkan dapat membantu dalam kelancaran dan penerapan aplikasi Implementasi Algoritma MD5 Untuk Keamanan LHS yang baru, agar tampilan pada

\section{REFERENSI}

[1] Akadun 2009. Teknologi Informasi Administrasi. Bandung : Alfabeta

[2] Kurniawan, Yusuf. (2004). Kriptografi Keamanan Internet dan Komunikasi Bandung: INFORMATIKA.

[3] Rinaldi Munir. 2006. Strategi Algoritmik. Laboratorium Ilmu dan Rekayasa komputasi-Institut Teknologi Bandung.

[4] Saipul Bahri. 2012. Studi dan Implementasi Pengamanan Basis Data Menggunakan Metode Enkripsi MD5 (Message-Digest Algorihm). 